\title{
Laparoscopic-assisted prepubic urethrostomy: experimental model in rabbit
}

\author{
Luciana Branquinho Queiroga ${ }^{*}$ Lucila Maria Almeida Lopes ${ }^{1}$ Giordano Cabral Gianotti $^{1}$ \\ Simone Scherer ${ }^{1}$ Marcelo Meller Alievi ${ }^{1}$ Carlos Afonso de Castro Beck ${ }^{1}$
}

${ }^{1}$ Departamento de Medicina Animal, Faculdade de Veterinária, Universidade Federal do Rio Grande do Sul (UFRGS), 91540-000, Porto Alegre, Brasil. E-mail: luqueirogavet@gmail.com. "Corresponding author.

\begin{abstract}
The purpose of this study was to develop a laparoscopic-assisted prepubic urethorstomy (PPU) technique using rabbits as an experimental model. Six male New Zealand rabbits (Oryctolagus cuniculus) over six months old and weighing between 3 and $4 \mathrm{~kg}$ (3.5kg \pm 0.4 ) were used in this study. The animals underwent laparoscopic dissection of the pelvic urethra, which was then exposed for the laparoscopicassisted urethrostomy procedure. The proposed model for training of laparoscopic-assisted PPU in rabbits was considered effective and feasible. It proved to be a simple technique even for surgeons under basic endosurgery skills training, with possibilities of employing the technique for the treatment of cats with loss of function of the distal urethra.
\end{abstract}

Key words: endosurgery, urethral surgery, laparoscopy.

Uretrostomia pré-púbica vídeo-assistida: modelo experimental em coelhos

RESUMO: Este estudo objetivou o desenvolvimento de uma técnica de uretrostomia pré-púbica (UPP) vídeo-assistida, utilizando coelhos como modelo experimental. Foram utilizados seis coelhos Nova Zelândia (Oryctolagus cuniculus), machos, com peso médio de $3.5 \mathrm{~kg}( \pm 0.4$ ), com idade acima de seis meses. Os animais foram submetidos à dissecação laparoscópica da uretra pélvica e posterior exposição desta para a realização de uretrostomia vídeo-assistida. O modelo proposto para treinamento de UPP vídeo-assistida em coelho foi considerado eficaz e factível, mostrando-se uma técnica exequivel mesmo por videocirurgiões iniciantes, havendo possibilidade de seu emprego no tratamento de gatos com perda na função da uretra distal.

Palavras-chave: videocirurgia, cirurgia uretral, laparoscopia.

\section{INTRODUCTION}

Feline lower urinary tract disease (FLUTD) can result in partial or complete obstruction of the urethra in male cats (BERNARDE \& VIGUIER, 2004; BASS et al., 2005). Failure in clinical management and recurrence of FLUTD may lead to urethral stenosis. Thus, perineal urethrostomy (PU) is indicated. However, some cases of distal urethra obstruction can not be treated using this procedure; in those cases, other techniques such as prepubic urethrostomy (PPU) or subpubic urethrostomy (BAINES et al., 2001) are indicated. Other conditions requiring PPU include: perineal urethra stenosis, traumas caudal to the pelvic urethra, granulomatous urethritis, and cutaneous lesions on the perineum, which can hinder a PU (BERNARDE \& VIGUIER, 2004).
Several endosurgery techniques have been developed in the research field as alternatives to conventional approaches. Experimental procedures should be widely assessed for feasibility, risks and benefits prior routine use in the surgical practice (BECK et al., 2003; BECK et al., 2004; BRUN et al., 2007; ISARIYAWONGSE, et al., 2008; BASSO et al., 2010). Additionally, the development of endosurgery skills by surgeons is gradual, and the learning curve can be reduced through training in experimental models (MOLINAS et al., 2004; SCHERER, 2009).

Since PPU by laparotomy is the current alternative for preserving the proximal urethra in cats, the purpose of this study was to develop a laparoscopic-assisted PPU technique using rabbits as an experimental model. 


\section{MATERIALS AND METHODS}

Six male New Zealand rabbits (Oryctolagus cuniculus) aging six months old and weighting between 3 and $4 \mathrm{~kg}(3.5 \pm 0.4 \mathrm{~kg})$ were used in this study. The animals were clinically evaluated and kept in individual cages, with a seven-day adaptation period. The rabbits received food and water ad libitum.

Prior surgery, animals were fasted for food and water, for four and two hours respectively. Subsequently, animals received $\mathrm{S}(+)$ ketamine hydrochloride $\left(15 \mathrm{mg} \cdot \mathrm{kg}^{-1}\right)$, midazolam $\left(2 \mathrm{mg} \cdot \mathrm{kg}^{-1}\right)$, and pethidine hydrochloride $\left(5 \mathrm{mg} \cdot \mathrm{kg}^{-1}\right)$, all intramuscularly. With the animals sedated, enrofloxacin $\left(5 \mathrm{mg} \cdot \mathrm{kg}^{-1}\right)$ was administered intramuscularly, and venous access was established with the infusion of Ringer's lactate solution at $10 \mathrm{~mL} \cdot \mathrm{kg}^{-1} \cdot \mathrm{h}^{-1}$. General anesthesia was induced with intravenous administration of propofol $\left(5 \mathrm{mg} \cdot \mathrm{kg}^{-1}\right)$. The patient was subsequently intubated, and anesthesia was maintained with isoflurane (1.5 $\mathrm{V} \%$ ) diluted in $100 \%$ oxygen using a rebreathing system. Analgesia was supplemented with fentanyl citrate, and anesthesia with propofol - titrated to effect whenever necessary.

After sedation, the ventral abdomen was widely clipped; the urinary bladder was evacuated by catheterization, and skin was prepared with $4 \%$ chlorhexidine. Animals were placed in Trendelenburg position, with foam pads used to raise the pelvic area. The procedure began with insertion of the first portal through the linea alba using the open technique, 2 to $3 \mathrm{~cm}$ caudal to the umbilicus. A 5-mm trocar was positioned for insertion of a $4-\mathrm{mm}^{\circ}$ rigid telescope. A $5-\mathrm{mmHg}$ $\mathrm{CO}_{2}$ pneumoperitoneum was created and maintained during surgery. Two additional 3-mm working ports were placed caudally, in triangulation with the first port, approximately $5-7 \mathrm{~cm}$ lateral to the midline port (Figure 1A).

After examination of the abdominal cavity, the bladder was located, and the urinary bladder trigone and pelvic urethra were identified. Blunt dissection of the urethra was performed close to the entrance of the pelvis. Dissection was performed carefully in order to preserve the trigone and proximal urethra's neurovascular supply (Figure 1B and 1C). After urethra dissection, a 5-mm minilaparotomy was performed for exteriorization of the urethra using an ovariectomy hook under laparoscopic assistance. Pneumoperitoneum was drained right after exposure of the urethra. Two stay sutures were placed on the urethra to aid manipulation. The abdomen was isolated using moistened laparotomy pads, and the urethra was transected transversally. A 6-Fr Foley catheter was inserted into the bladder to minimize urine leakage, and was removed soon after fixation of the urethra. The distal aspect of the urethra was obliterated using simple interrupted sutures with 4-0 absorbable multifilament suture material and repositioned into the abdominal cavity. To create the urethral orifice on the proximal aspect of the urethra, the angle between the bladder and the urethra had to be lower than $45^{\circ}$ to avoid kinking of the urethra (Figure 1D). The urethral mucosa was sutured to the skin using simple interrupted sutures with atraumatic needle and 4-0 poliglactine 910 thread (Figure 1E and 1F). Pneumoperitoneum was reestablished to inspect the abdominal cavity. After this inspection, the trocars were removed, and $\mathrm{CO}_{2}$ was removed from the abdominal cavity. Abdominal port incisions were closed, and the skin was sutured using simple interrupted sutures with 4-0 poliglactine 910 thread. Surgeries were carried out by a surgical team on the beginning of the learning curve of laparoscopic surgery.

All animals received enrofloxacin $\left(5 \mathrm{mg} \cdot \mathrm{kg}^{-1}\right)$ BID for 5 days, tramadol hydrochloride $\left(4 \mathrm{mg} \cdot \mathrm{kg}^{-1}\right)$ TID for 5 days, and ketoprofen $\left(3 \mathrm{mg} \cdot \mathrm{kg}^{-1}\right)$ SID for three days, intramuscularly, for post-op care.

Animals were subjected to euthanasia as suggested by SPINOSA AND SPINOSA (2011). Two animals were euthanized per week starting on the second week after surgery, for a total of one month of clinical evaluation. Animals undergone necropsy as soon as euthanasia was carried out.

Laparoscopic-assisted PPU were divided into intraoperative steps. Time to achieve each intraoperative step were recorded as follows: T1 - from skin incision until manipulation of the abdominal urethra; T2 - dissection of urethra until exposure; T3 - exposure of the abdominal urethra until fixation of the urethra to the abdominal wall; T4 - From transection of the urethra to urethra/ skin suture; T5 - time of pneumoperitoneum, which represents the time used for exposure of the urethra and inspection of the urethrostomy at the end of the procedure. OST - overall surgical time, from the first incision up to skin suture.

\section{RESULTS}

Mild or moderate bleeding occurred during transection of the urethra and fixation in the 


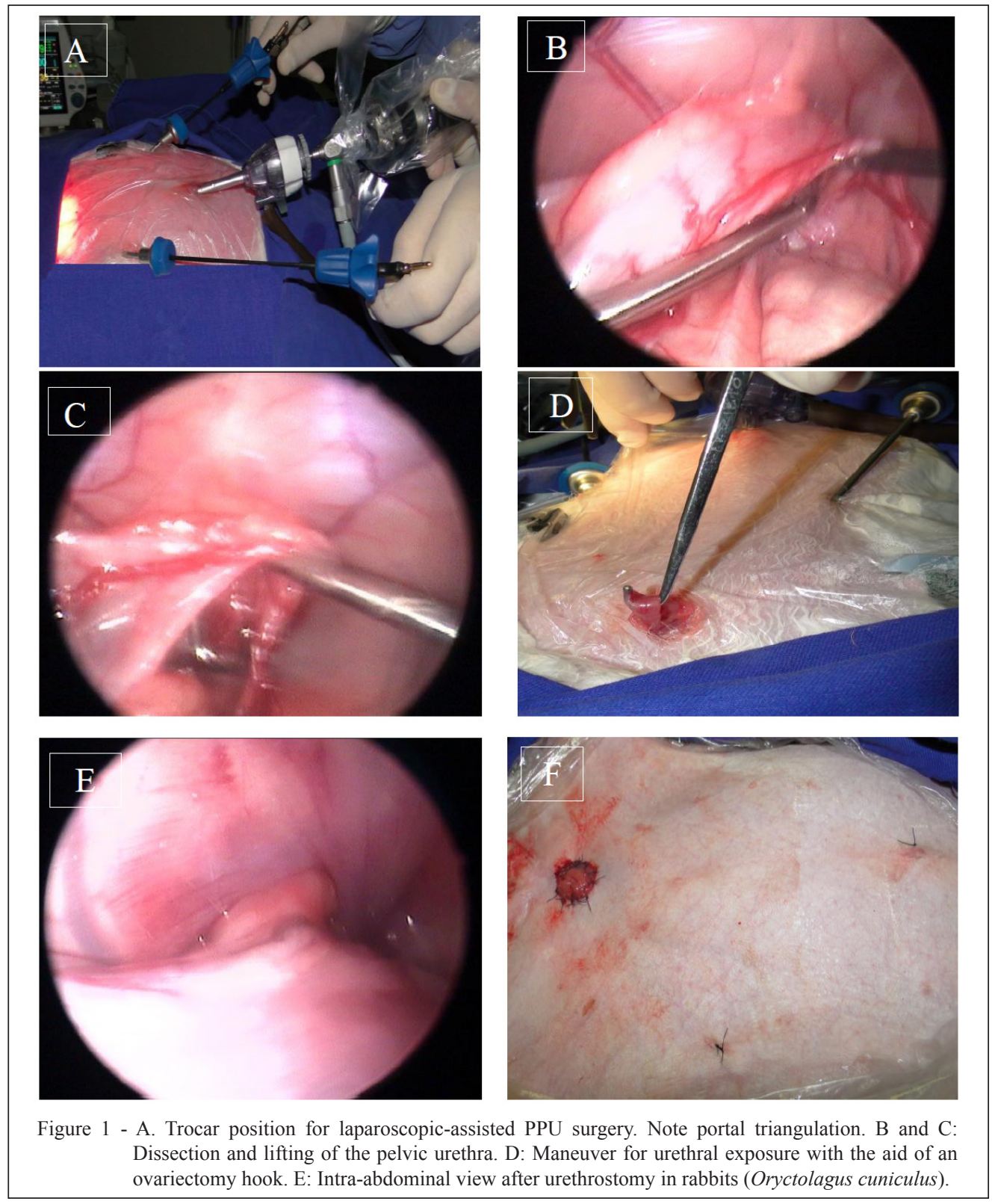

abdominal wall; bleeding decreased as sutures were placed. Subcutaneus emphysema occurred in four animals following pneumoperitoneum establishment; emphysema was reduced at the end of the procedure through skin massage.

Time elapsed for execution of intraoperative steps and overall surgical time of laparoscopic-assisted PPU are displayed in table 1 . Total surgical time ranged from 47 to 60 minutes (mean 55 minutes \pm 5 ).

Seven animals had transitory urinary incontinence in the first four days following surgery; only one rabbit remained incontinent for 10 days.
Dermatitis occurred surrounding the urethral orifice during incontinence.

Necroscopic examination revealed suture properly placed and absence of subcutaneous inflammation close to the urethral orifice in all animals. Hematuria ocurred on the first three days in two rabbits.

The orifice created through laparoscopicassisted PPU provided proper urinary diversion in all animals, with no need for enlargement of the distal end of the urethra.

In one of the animals, a partial bladder prolapse was observed in the immediate post-

Ciência Rural, v.48, n.1, 2018. 
Table 1 - Time elapsed for execution of intraoperative steps and overall surgical time of laparoscopic-assisted prepubic urethrostomy in rabbits (Oryctolagus cuniculus).

\begin{tabular}{|c|c|c|c|c|c|c|}
\hline No. & $\mathrm{T} 1(\min )$ & $\mathrm{T} 2(\min )$ & $\mathrm{T} 3(\min )$ & $\mathrm{T} 4$ (min) & $\mathrm{T} 5$ (min) & OST (min) \\
\hline 1 & 10 & 19 & 18 & 7 & 22 & 54 \\
\hline 2 & 9 & 25 & 18 & 6 & 28 & 58 \\
\hline 3 & 10 & 23 & 18 & 9 & 25 & 60 \\
\hline 4 & 14 & 18 & 10 & 5 & 21 & 47 \\
\hline 5 & 11 & 18 & 16 & 6 & 23 & 51 \\
\hline 6 & 15 & 15 & 20 & 10 & 28 & 60 \\
\hline MEAN (SD) & $11( \pm 2)$ & $19( \pm 3)$ & $16( \pm 3)$ & $7( \pm 2)$ & $24( \pm 3)$ & $55( \pm 5)$ \\
\hline
\end{tabular}

T1 - Time elapsed from skin incision until manipulation of the abdominal urethra. T2 - Dissection of urethra until its exposure. T3 Exposure of the abdominal urethra until its attachment to the abdominal wall. T4 - Execution of PPU until skin suture. T5 - Sum of time under pneumoperitoneum from beginning of the procedure until exposure of the urethra and time for inspection after urethrostomy. Total surgical time (TST) - includes time from skin incision up to skin suture.

operative period, which was spontaneously resolved two days after surgery.

\section{DISCUSSION}

Trendelenburg positioning and triangulation close to the pelvic area allowed manipulation of the pelvic urethra without manipulation of the bowels during procedure. Trocar positioning provided optimal visualization of the bladder, urethra, and ureters in all animals. Low-pressure pneumoperitoneum was used in this trial $(5 \mathrm{mmHg})$. Other studies reported higher intraperitoneal pressure for laparoscopic approach in rabbits (BECK et al., 2003; MOLINAS et al., 2004). Lowpressure pneumoperitoneum provided both excellent view and safe tissue handling in this study. Moreover, lower pneumoperitoneum pressure minimizes possible respiratory and cardiovascular distress and postoperative morbidity (SCHIOCHET, 2006).

During urethra dissection, special care was taken to avoid trauma to blood supply and innervation, which was considered relevant for surgical success (BAINES et al., 2001, CAMPBELL, 2003). Fine and precise dissection maneuver was improved by magnification provided by videoendoscopic system, as stated by others (FREEMAN, 1998).

Exposure of the urethra was performed using an ovariectomy hook under visualization with laparoscopic guidance. The urethra was maintained in contact with the abdominal wall. Moreover, the ovariectomy hook served as a guide for the incision of the urethral orifice, which increased precision and eliminated the need for a larger incision.

The surgical procedure followed the same principles as for PPU by laparotomy with regard to the establishment of the urethral orifice, with care taken to avoid tension and angulation of the urethra while creating the orifice (BAINES et al., 2001, CAMPBELL, 2003). The stay sutures allowed precise manipulation of the exposed urethra without causing further damage. The suture material used was adequate for fixation of the urethra to the skin in all animals.

Since urethra dissection was carried out close to the pelvis and over the intrapelvic urethra, neurovascular damage close to the vesicourethral junction was safely avoided. The physiological voiding process involved the smooth muscles of bladder and the internal and external urethral sphincter. Nerve fibers responsible for vesical sphicter competence are is located close to the trigone (BAINES et al., 2001; BERNADE \& VIGUIER, 2004; FOSSUM, 2005; PHILLIPS \& HOLT, 2006).

Dermatitis has also been reported in cats undergone PPU (BAINES et al., 2001). Skin healed as internal sphincter became functional. Cats which undergone PPU also had substantial improve on quality of life following urinary continence recovery (BAINES et al., 2001; CAMPBELL, 2003; BASS et al., 2005). Hematuria is also a common selflimiting complication in cats by BASS et al. (2005), BERNARDE \& VIGUIER (2004), and PHILLIPS \& HOLT, (2006). Complications observed in the present study are well documented in conventional prepubic urethrostomy techniques (MCLAREN, 1988; LEÓN et al., 1997; BAINES et al., 2001; BERNADE \& VIGUIER, 2004; BASS et al., 2005; ADDISON et al., 2013).

The bladder prolapse probably occurred due to the post-operative anesthetic relaxation and to 
the larger diameter of the pelvic urethra in rabbits. This complication has not been reported in cats.

Reported variations of the laparotomy technique include changes in the location of the urethral orifice or pubic osteotomies (MCLAREN, 1988; BAINES et al., 2001; BERNADE \& VIGUIER, 2004). To the authors' knowledge, the laparoscopic-assisted PPU technique was not been reported in the small animal setting. The main goal of laparoscopic-assisted PPU reported in this study was both preserving urinary flow and future obstructions. This technique does not avoid occurrence of FLUTD signs, since magnitude of the urethra is drastically reduced, urethral diameter is enlarged, and anatomical natural barriers are limited (BAINES et al., 2001; FOSSUM, 2008).

A variation of the technique described in these study was successfully carried out for laparoscopic PPU as a way to preserve the proximal urethra in a cat following unsuccessful PU (FILHO et al., 2014). Thus, the authors truly believe that the technique reported in this study has great potential for practical clinical use in the small animal setting.

\section{CONCLUSION}

The laparoscopic-assisted laparoscopic PPU technique in the rabbit model is feasible and should be considered for further treatment of cats bearing distal urethra obstructive disorders.

\section{BIOETHICS AND BIOSSECURITY COMMITTEE APPROVAL}

The present study has been approved by the Comissão de Ética no Uso de Animais (CEUA) of Universidade Federal do Rio Grande do Sul (UFRGS) ( protocol number 19465).

\section{REFERENCES}

ADDISON, E. S. et al. A retrospective analyses of urethral rupture in 63 cats. Journal of Feline Medicine and Surgery, v. 16, n. 4, p. 300 - 309, oct. 2013. Available from: <http://journals.sagepub. com/doi/abs/10.1177/1098612X13508194?journalCode=jfma $>$. Accessed: mar. 11, 2017. doi: 10.1177/1098612X13508194.

BAINES, S.J. et al. Prepubic Urethrostomy: a long-term study in 16 cats. Veterinary Surgery, v. 30, p. 107-113, mar. 2001. Available from: <onlinelibrary.wiley.com/doi/10.1053/jvet.2001.20327/pdf>. Accessed: jan. 27, 2015. doi: 10.1053/jvet.2001.20327.

BASS, M. et al. Retrospective study of indications for and outcome of perineal urethrostomy in cats. Journal of Small Animal Pratice. v. 46, p. 227 - 231, may 2005. Available from: <onlinelibrary.wiley. com/doi/10.1111/j.1748-5827.2005.tb00314.x/pdf>. Accessed: jan. 27, 2015. doi: 10.1111/j.1748-5827.2005.tb00314.x.
BASSO, P.C. et al. Herniorrafia perineal, ressecção de cisto prostático e criptorquidectomia vídeolaparoscópicas por único acesso em cão. Ciência Rural, v. 40, p. 479-483, 2010. Available from: <http:// www.scielo.br/pdf/cr/v40n2/a447cr2347.pdf $>$. Accessed: feb. 18, 2015. doi: 10.1590/S0103-84782010005000001.

BECK, C.A.C. et al. Criptorquidectomia em coelhos: modelo experimental para tratamento laparoscópico. Ciência Rural, v.33, n. 2, p.331-337, 2003. Available from: <http://www.scielo.br/ $\mathrm{pdf} / \mathrm{cr} / \mathrm{v} 33 \mathrm{n} 2 / 15225 . \mathrm{pdf}>$. Accessed: feb. 18, 2015. doi: 10.1590/ S0103-84782003000200023.

BECK, C.A.C. et al. Laparoscopia nas hérnias diafragmáticas: estudo experimental em cães. Ciência Rural, v.34, n. 6, p.18491855, 2004. Available from: <http://www.scielo.br/pdf/cr/v34n6/ a28v34n6.pdf $>$. Accessed: feb. 18, 2015. doi: 10.1590/S010384782004000600028

BERNARDE, A.; VIGUIER, E. Transpelvic urethrostomy in 11 cats using an ischial ostectomy. Veterinary Surgery, v. 33, p. 246-252, apr. 2004. Available from: <onlinelibrary.wiley.com/ doi/10.1111/j.1532-950X.2004.04036.x/pdf> Accessed: jan. 27, 2015. doi: 10.1111/j.1532-950X.2004.04036.x.

BRUN, M.V. et al. Colopexia laparoscópica com retalho de tela de polipropileno em cães. Arquivo Brasileiro de Medicina Veterinária e Zootecnia, v.59, n. 1, p.119-126, 2007. Available from: $<$ http://www.scielo.br/pdf/abmvz/v59n1/20.pdf $>$. Accessed: feb. 18, 2015. doi: 10.1590/S0102-09352007000100020.

CAMPBELL, B.G. Prepubic urethrostomy and placement of a caudal superficial epigastric flap for treatment of a selfmutilation injury in a serval. Journal of the American Veterinary Medical Association, v. 222, n. 5, p. 628-632, mar. 2003. Available from: <http://avmajournals.avma.org/doi/pdf/10.2460/ javma.2003.222.628>. Accessed: feb. 18, 2015. doi: 10.2460/ javma.2003.222.628.

FILHO, S. T. L. P. et al. Uretrostomia pré-púbica videoassistida em um felino com estenose uretral. Semina: Ciências Agrárias, v. 35, n. 1, p. 381-386, 2014. Available from: $<$ http://www.uel.br/revistas/ uel/index.php/semagrarias/article/view/14477>. Accessed: jan. 14, 2016. doi: $10.5433 / 1679-0359.2014 \mathrm{v} 35 \mathrm{n} 1 \mathrm{p} 381$.

FOSSUM, T.W. Cirurgia em Bexiga e Uretra. In: Cirurgia de Pequenos Animais. São Paulo: Roca, 2008. p. 582-583.

FREEMAN, L.J. Operating room setup, equipment, and instrumentation. In: FREEMAN, L.J. Veterinary endosurgery. St Louis: Mosby, 1998. Cap.1, p.3-23.

ISARIYAWONGSE, J.P. et al. Pure natural orifice transluminal endoscopic surgery (notes) nephrectomy using standard laparoscopic instruments in the porcine model. Journal of Endourology, v, 22, n. 5, p. 1087-1092, may 2008. Available from: <online.libertpub. com/doi/abs/10.1089/end.2007.0404>. Accessed: jan. 15, 2015. doi: 10.1089/end.2007.0404.

MCLAREN, I.G. Prepubic urethrostomy involving transplantation of the prepuce in the cat. The Veterinary Record, v. 122, p. 363, 1988. Available from: <https://www.veterinaryrecord.bmj. com/content $/ 122 / 15 / 363.1$.short $>$. Accessed: feb. 19, 2015. doi: 10.1136/vr.122.15.363.

MOLINAS, C.R. et al. The rabbit nephrectomy model for training in laparoscopic surgery. Human Reproduction, v. 19, n. 1, p. 185- 
190, jan. 2004. Available from: <http://humrep.oxfordjournals.org/ content/19/1/185.full.pdf +html>. Accessed: feb. 18, 2015. doi: 10.1093/humrep/deh025.

PHILLIPS, H.; HOLT, D.E. Surgical revision of the urethral stoma following perineal urethrostomy in 11 cats: (1998-2004). Journal of the American Animal Hospital Association, v. 42, n. 3, p. 218-222, 2006. Available from: <https://www.jaaha.org/doi/pdf/1053.26/0420218>. Accessed: feb. 19, 2015. doi: 10.5326/0420218.

SCHERER, S. Desenvolvimento de modelo experimental em cadáver de cão conservado com a solução de Larssen modificada para treinamento em videocirurgia: Nefrectomia total e tireoidectomia. 2009. 77f. Dissertação de Mestrado em Cirurgia Veterinária da Faculdade de Veterinária da Universidade Federal do Rio Grande do Sul, Porto Alegre.
SCHIOCHET, F. Ovário-salpingo-histerectomia laparoscópica em felinos em felinos hígidos. 2006. 91f. . Dissertação de Mestrado em Cirurgia Veterinária da Faculdade de Veterinária da Universidade Federal do Rio Grande do Sul, Porto Alegre.

SPINOSA, H. S.; SPINOSA, F. R. N. Eutanásia. In: SPINOSA, H. S.; GORNIAK, S. L.; BERNARDI, M. M. Farmacologia aplicada à medicina veterinária. 5. ed. Rio de Janeiro: Guanabara Koogan, 2011. Cap: 62, p. 762-767.

STEDILE, R. et al. Laparoscopic versus open splenectomy in dogs. Pesquisa Veterinaria Brasileira. vol. 29, n. 8, p. 653 - 660, aug. 2009. Available from: <www.scielo.br/ scielo.php? pid=S0100-736X2009000800009\&script $=$ sci arttext>. Accessed: jan. 27, 2015. doi: 10.1590/S0100736X2009000800009. 